\title{
PKM Online Classroom Management Training Based on Google Classroom and Edpuzzle Applications at SMP Negeri 1 Probolinggo
}

\author{
Hefniy ${ }^{1}$, Yudik Al Farisi ${ }^{2}$, Ach. Qusairi ${ }^{3}$, Muhammad Amiruddin ${ }^{4}$, \\ Alip Al Mahdi ${ }^{5}$, Muhammad Wahyu Fajry ${ }^{6}$, Abdullah Haq Reshufle ${ }^{7}$, \\ Ahmad Nuvi ${ }^{8}$, Muhammad Fadali Amar ${ }^{9}$, M. Nurul Al Zaman ${ }^{10}$, \\ Moh. Hidayatullah ${ }^{11}$, Siti Masruroh ${ }^{12}$, Ahmad Muktashim Billah' ${ }^{13}$, \\ Hoirul Anwar Maulana ${ }^{14}$, Sodikin $^{15}$, Moh. Hasyim ${ }^{16}$
}

Universitas Nurul Jadid, Probolinggo, Indonesia 1,2,3,4,5,6,7,8,9,10,11,12,13,14,15,16

$\left\{\right.$ hefniy@gmail.com ${ }^{1}$, yudi@unuja.ac.id $\left.{ }^{2}\right\}$

\begin{tabular}{l} 
Submission: 20/12 \\
\hline Keywords: \\
Training, Google \\
classroom, \\
Edpuzzle, Online \\
Learning.
\end{tabular}

Katakunci:

Pelatihan,

Google

Classroom,

Edpuzzle,

Pembelajaran

Online
Abstract. The purpose of this service activity is to improve the ability of teachers at SMP Negeri 1 Probolinggo in managing online classes by providing online class management training based on the Google Classroom and Edpuzzleapplications. The method of implementing this activity is lecture, practice, and discussions. Lectures were conducted to deliver material on the stages of classroom management using Google Classroom and using videos on Edpuzzle. The participants of this activity were all teachers of SMP Negeri 1 Probolinggo, a total of 40 people. For online class management, participants were given training in class management and grades, using forums, and making materials and quizzes. For the use of videos as learning materials, participants were trained in choosing videos, editing videos, inserting messages and questions, and multiple choices. The results of this service activity are as many as72.5\% of participants have been able to manage online classes and integrate with Edpuzzle. Partners have also agreed to use Google Classroom's added puzzle for learning for the 2021/2022 academic year. 
kegiatan pengabdian ini adalah sebanyak $72,5 \%$ peserta telah mampu mengelola kelas online dan berintegrasi dengan Edpuzzle. Mitra juga telah setuju untuk menggunakan teka-teki tambahan Google Classroom untuk pembelajaran untuk tahun akademik 2021/2022.

\section{Introduction}

Teaching and learning activities during this pandemic are carried out online according to UU No. 4 of 2020 concerning the Implementation of Internal Education PoliciesThe Emergency Period for the Spread of Coronavirus Disease (Covid-19) issued by the MinisterEducation and Culture (Na'im 2020). Teachers and students face many challenges. Teachers must change the form of teaching preparation (RPP) in online conditions.

The teacher must adjust several things, such as material delivery techniques, teaching techniques, delivery of assignments, assessment techniques, turning on the virtual classroom atmosphere, and communicating and providing consultation to students (Nur Khairiyah Mar'aha, 2020)(Basar, 2021). This adjustment is needed so that the teaching and learning process still has the same quality as face-to-face learning. Even more, the quality can be improved. Improving the quality of learning is very important so that students can compete in this sophisticated and modern era (Ida, 2020). Process improvement quality learning is expected to align with the development and demands of the applicable curriculum (Sobri, 2014).

Using technology for the teaching and learning process, many teachers take advantage of the WhatsApp Group (WA Group) feature to manage their online classes. The use of the WA Group is considered easy and well understood by students. However, there are obstacles in managing all the digital documents in the WA Group. Data scattered students on many digital documents to cell phone memory that fills up very quickly (Ni'mah,2021) (Augustini, 2020). This situation is also experienced by junior high school teachers inProbolinggo City, SMP Negeri 1 Probolinggo. Even though this school is located in Probolinggo City, digital document management is unavoidable. Some teachers utilize the WA Group to deliver materials, assignments and coordinate with students in class. Some teachers have used Google Classroom to learn. This disparity in online learning activities creates problems in implementation. The problems faced are assigning assignments, recording grades, and reporting student progress to parents. In addition, the 
teacher also can not ensure well whether students have watched the learning material delivered via video. So that even the teachers do not know the level of student's understanding of the material provided.

To help teachers deal with organizational problems online learning, training on the use of Google Classroom and Edpuzzle for teachers at SMP Negeri 1 Probolinggo. This training activity's objectives are: 1 ) Train teachers in managing classes, materials, and grades in GoogleClassroom and 2) Train teachers to use Edpuzzle in delivering material video form. With this training, it is hoped that the teachers at SMP PGRI 5Probolinggo can manage online classes more effectively and efficiently.

\section{Method}

In this training, lecture, practice, and discussion techniques are used to deliver the material.

1. Lecture technique to convey the features and steps in using Google Classroom and Edpuzzle, it aims to provide an overview to the trainees related to the application used.

2. Discussion techniques are carried out to provide opportunities for training participants to apply the material used to understand the related given material.

3. Discussion techniques are carried out to allow participants to get feedback on the obstacles faced when applying the acquired theory.

To carry out these training steps, before training activities, has been carried out through several stages as follows.

1. PreparationThis stage includes the following activities:

a. Coordinate with partners to conduct needs analysis training.

b. Determine the time and place of implementation.

c. Cooperating with partners.

d. Prepare the tools and materials needed to implement the training.

2. Implementation

In the training implementation stage, this activity involves training partners. The training provided is in the form of using Google Classroom and Edpuzzle to online learning classroom management. 
3. Evaluation and follow-up

Evaluation of partner capacity building for online classroom management carried out before and after training. Evaluation before training in the form of filling out questionnaires related to learning applications that have been done. Resultsfilling out the questionnaire showed that as many as 40teachers already know the Google Classroom application. However, only $32.5 \%$ of teachers use Google Classroom regularly. In addition, the trainees one has integrated Google Classroom with Edpuzzle yet. Process evaluation after training is carried out by giving assignments to make classes, organizing classes, utilizing forums, uploading materials and assignments, organizing assessments, and using video material in Edpuzzle. Based on tasks collected by the trainees, it is known that 29 people, or $72.5 \%$ of the teacher, has managed to take advantage of the features that have been taught during the training for the classes they teach. This also includes integrating google Classroom with Edpuzzle. The rest, as many as 11 trainees still having problems arranging assessments and inserting questions on video with Edpuzzle integrating Google Classroom with Edpuzzle. The rest, as many as 11 trainees, are still having problems arranging assessments and inserting questions on video with Edpuzzle.

\section{Result and Discussion}

In the preparation stage, STMIK Primakara visited SMP Negeri 1 Probolinggoto to discuss partners' readiness to receive team visits, determine training needs that can be carried out for partners, and determine the time implementation of training. This preparatory activity was carried out for two months. On the 7th July, 2021 online class management training using Google Classroom will be held and Edpuzzle in the Hall of SMP Negeri 1 Probolinggo, which all teachers at partner schools attended.

During interviews with partners, problems faced by teachers at SMP Negeri 1 Probolinggo is document management online learning and delivery of material in the form of videos. To help cope withln this situation, training that focuses on the problems at hand is needed. WrongOne way to manage online learning is to use Google Classroom. Google Classroom is an 
application from Google intended to manage online learning. Google Classroom can make it easier for teachers to manage the class and make it easier for students to communicate with students-teacher (Sabran \& Sabara, 2020) (Atikah, Prihatin, Hernayati, \& Misbah, 2021).

The features provided by Google Classroom for teachers include class, inviting students to join the class, making assignments, taking quizzes, assigning grades to student assignments, and giving back the assessment results to students. Teachers will also be facilitated with features that can create attachments in documents, videos, and links and be directly connected to Google Drive storage belonging to the teacher. Teachers can also make arrangements regarding the schedule for uploading materials and the deadline for submitting assignments for students. Access to Google Classroom is also very easy. Google Classroom can be accessed through the website and applications on mobile phones.

Google Classroom can also be integrated with several learning platforms. One of the platforms that can be integrated with Google Classroom is Edpuzzle. Edpuzzle is a video-based learning application that can be accessed via smartphones, laptops, and PCs. Learning videos can be made by teachers or videos taken from Youtube, Crash Course, National Geographic, TEDTalks, or Khan Academy. Videos included in Edpuzzle can be edited by the teacher as needed. For example, adding notes and questions in between videos. The uniqueness of this Edpuzzle application is that the video cannot be continued if the students do not answer the questions that arise first, thereby reducing the possibility students speed up the video to the end. Students must watch the video carefully to answer the question because the questions will be related to the material presented in the video. Students can also repeat the video presented accordingly with their needs. This Edpuzzle can make it easier for teachers to monitor student learning activities, especially those that use learning videos. Watching videos accompanied by quizzes can also increase students' interest in learning the presented material. Learning activities carried out by students can be monitored by teachers in the Edpuzzle and Google Classroom applications easily (Sirri \& Lestari, 2020).

Based on the condition of the school above, training on the use of Google Classroom and integration with Edpuzzle in managing online classes focus on the following. 
1. Utilization of Google Classroom in making class arrangements, setting grades, use of forums, and making materials and quizzes.

2. The use of Edpuzzle for materials, notes, and quizzes in the form of videos integrated into Google Classroom.

In implementing the training, the material was opened by conveying the importance of expertise for the 21st century (21stCentury Learning Skills ) associated with abilities teachers in online classroom management. All trainees have used several online applications in classroom management. However, the intensity of its use is still sufficiently low. The $42.5 \%$ of participants only use online applications in class management once a week. The use of Google Classroom is also only integrated with Google Meet. There are no trainees who have integrated Google Classroom with Edpuzzle. The training results are an online class on Google Classroom for learning classes in the odd semester academic year 2021/2022 at SMP Negeri 1 Probolinggo. The Google Classroom classes created by the trainees are integrated with the video in Edpuzzle. 72.5\%the trainee teachers have managed their classes and teaching materials well. The teachers have organized classes, set grades, utilized forums, created materials, quizzes, and topics on Google Classroom. Teachers can also share a link for learning grades students to parents as reporting student learning outcomes. For the Edpuzzle app, the teacher can use the video search and then modify it according to learning needs. Modifications are made in the form of adding notes and questions in between videos given. Activity implementation of training and classroom management results using Google Classroom and Edpuzzle by the teacher is presented in the following pictures.

Short-term follow-up of this activity will be planned and supervised by partners. The team will monitor partner activities, mentoring, and provide direction and solutions to implementing online classroom management problems. For long-term follow-up, target the next step is to measure the effectiveness of using Google Classroom and Edpuzzle in learning online classroom management. 


\section{Conclusion}

The conclusion obtained from this community service activity is training online class management using Google Classroom. Edpuzzle is very easy for partners to manage online learning, from providing materials and exercises to returning student work and using video learning as a learning material to increase learning effectiveness. As for suggestions that can be submitted based on the results of this activity, it is necessary to provide guidance and training in online classroom management so that learning objectives can be achieved and online classes get more fun.

\section{References}

Agustini, N. P. (2020). Penggunaan Media Sosial Whatsapp Pada Pembelajaran Agama Hindu Untuk Di Masa Pandemi. Jurnal Widya Sastra Pendidikan Agama Hindu, 67- 72.

Atikah, R., Prihatin, R. T., hernayati, H., \& Misbah, J. (2021). Pemanfaatan Google Classroom Sebagai Media Pembelajaran Di Masa Pandemi Covid-19. Jurnal PETIK, 7-18.

Basar, A. M. (2021). Problematika Pembelajaran Jarak Jauh Pada Masa Pandemi Covid-19. Edunesia : Jurnal IImiah Pendidikan, 208-218.

Ida Bagus Nyoman Mantra, I. A. (2020). Peningkatan Kompetensi Mengajar Secara Online Bagi Para Guru Selama Pandemi Virus Corona. Jurnal Abdi Dharma Masyarakat, 12- 20.

Ni'mah, S. F. (2021). Penggunaan Whatsapp Group dalam Meningkatkan Motivasi Belajar Siswa pada Mata Pelajaran IPS Kelas VIII di MTsN 1 Bojonegoro. Malang: Universitas Islam Negeri Maulana Malik Ibrahim .

Nur Khairiyah Mar'aha, A. R. (2020). Perubahan Proses Pembelajaran Daring Pada Siswa Sekolah Dasar di Tengah Pandemi Covid-19. SEMINAR NASIONAL PASCASARJANA 2020 (pp. 445-452). Semarang: Universitas Negeri Semarang.

Sabran, \& Sabara, E. (2020). Keefektifan Google Classroom sebagai Media Pembelajaran. "Diseminasi Hasil Penelitian melalui Optimalisasi Sinta dan Hak Kekayaan Intelektual" (pp. 122-125). Makassar: Lembaga Penelitian Universitas Negeri Makassar. 
Sirri, E. L., \& Lestari, P. (2020). Implementasi Edpuzzle Berbantuan Whatsapp Group sebagai Alternatif Pembelajaran Daring pada Era Pandemi. Jurnal Pendidikan Matematika Indonesia, 67-72.

Sobri, M. (2014). Efektivitas Pembelajaran Media E-Learning Berbasis Web dan Konvensional Terhadap Tingkat Keberhasilan Belajar Mahasiswa (Studi Kasus Mahasiswa Fakultas Ekonomi Universitas Bina Darma Pa 